\title{
ASSESSMENT OF SCHOOL AND INDUSTRIAL Noise: Measurements vs Personal PERCEPTIONS
}

\section{VujicA Herzog, N., BuchmeIster, B., \& SPINDLER, L.}

Abstract: Generally, noise is a considerable stress factor in several workplaces and living environments. Despite legal regulations and recommendations, there are still many problems resulting from noise exposure, especially extra-aural effects. We studied the influence of noise on workers in two different environments: A Technical High School and a manufacturing company. Measurements of noise levels were performed, together with corresponding noise frequency analysis. In both cases, working places were found where the noise levels exceeded the upper exposure level of $85 \mathrm{~dB}(\mathrm{~A})$. In comparison to measurements, personal noise perceptions of workers were assessed by an extended research survey. Correlating the survey's results and experimentally determined noise levels gave us new insights into the occupational health risks of noise in two very different working environments.

Key words: noise measurements, high school, manufacturing company, survey research, extra-aural effects
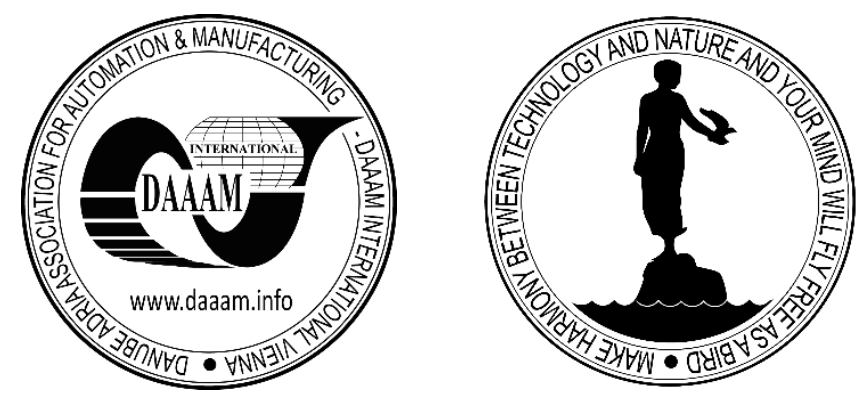

Authors' data: Assoc. Prof. Dr. Sc. Vujica Herzog, N[atasa], Full. Prof. Dr. Sc. Buchmeister, B[orut]; Asist. Prof. Dr. Sc. Spindler, L[ea];University of Maribor, Faculty of Mechanical Engineering, Smetanova 17, 2000 Maribor, Slovenia, natasa.vujica@um.si, borut.buchmeister@um.si, lea.spindler@um.si

This Publication has to be referred as: Vujica Herzog, N[atasa]; Buchmeister, B[orut] \& Spindler, L[ea] (2020). Assessment of School and Industrial Noise: Measurements vs Personal Perceptions, Chapter 03 in DAAAM International Scientific Book 2020, pp.033-048, B. Katalinic (Ed.), Published by DAAAM International, ISBN 978-3-902734-27-3, ISSN 1726-9687, Vienna, Austria

DOI: $10.2507 /$ daaam.scibook.2020.03 
Vujica Herzog, N.; Buchmeister, B. \& Spindler, L.: Assessment of School and Indu...

\section{Introduction}

Due to modern lifestyle and work, millions of workers worldwide are exposed to noise at work and its consequences (Giorgi et al., 2014; Yan \& Jiang, 2014; Harari et al., 2017; Lee at al., 2017). The higher the level of noise exposure, the higher the risk for injuries and health damage. There are certain Standards which give recommendations for the highest allowed noise levels, like ISO 1996-2 (2007), ISO/DIS 1996-1 (2016), ISO 9613-2 (1996), but, in practice, there are still many problems resulting from noise exposure, which implies that this area is not researched and documented enough (Ali, 2011, 2013; Gilavand, 2016; Sajin et al., 2019). Working environment with working conditions (noise, heat, illumination, air velocity), is one of the most important factors that influence stress at work and should be, with other important factors (Vujica et al., 2019; Buhmeister et. Al., 2019), carefully considered.

The consequences of noise can be hearing loss (aural effect), but also the whole organism can be affected (extra-aural effects). In accordance with the European recommended criteria (Directive 2003/10/EC), a professional hearing impairment includes only aural noise effects (Directive 2003/10/EC). Extra-aural effects are also harmful, but they are not on the European list, nor on the Slovenian list of professional diseases. Therefore, it is essential to perform more research on these occupational health risks and give suggestions for elimination of harmful effects of noise connected with numerous work related diseases.

Noise is an unpleasant, commonly loud sound to which workers in manufacturing and other industries worldwide are exposed daily, but is also found in schools (Sajin et al. 2019, Xie \& Tompsett, 2011; Vilcekova et al., 2017; Sadick \& Issa, 2017; Akboga et al., 2019), traffic (Wang et al., 2017; Distefano \& Leonardi, 2019), bars, orchestras, and also personal music players (Argalasova et al., 2016). Even lower degrees of noise can cause stress for the affected person; reactions are shown on both the physical and psychical levels, and long lasting exposure to noise leads to permanent hearing impairment. For workers exposed to noise, it is important to follow the noise levels at their working place regularly in order to evaluate the level of risk for hearing losses and damages and, accordingly, take the measures for managing or preventing risks.

In our study, the measurements of noise levels and corresponding frequency analysis were performed in two very different working environments. The first working place was industrial, focusing on production workers (Alba company, that deals with the manufacture of measuring instruments) and the second was educational, focusing on teachers` work (Technical High School Ravne). Workers from both working environments also completed a questionnaire, which related the results of measurements to the workers' subjective response to noise. Comparison of perceived and measured noise is not common practice in manufacturing environment. There were some individual researches performed in the past in different environment, such as schools (Sajin et al., 2019; Chetoni et al., 2016), assessment of noise levels of daily activities (Beach et al., 2011) and also for a road traffic noise exposure assessment, where ICBN scale was used (Brink et al., 2016). Due to the lack of questionnaires in the field of manufacturing, we developed with special care a survey tailored for manufacturing environment. 


\section{Methodology}

\subsection{Research framework}

Measurements of noise level and survey research methodology were taken up in two different environments, a high school and a manufacturing company, to study the presented problem. Fig. 1 presents our overall research framework. At the end of the performed measurements and analyses of survey research results, the comparison was made for both environments aimed at assessing the gathered results. The research was divided as follows:

a. Exact measurements of noise were made at the high school and in selected workshops in the manufacturing company;

b. A wide-ranging analysis of the existent literature was conducted, aimed at determining the major characteristics of noise;

c. A questionnaire was designed (Nunnally \& Bernstein, 1994; Lynn, 1999), in order to investigate the noise problems, pre-tested in an academic environment and selected individuals from the target research group, and later surveyed in the high school and in the manufacturing company. This questionnaire contained 22 items for teachers and 23 items for manufacturing workers;

d. The resulting data were then analyzed using descriptive statistics.

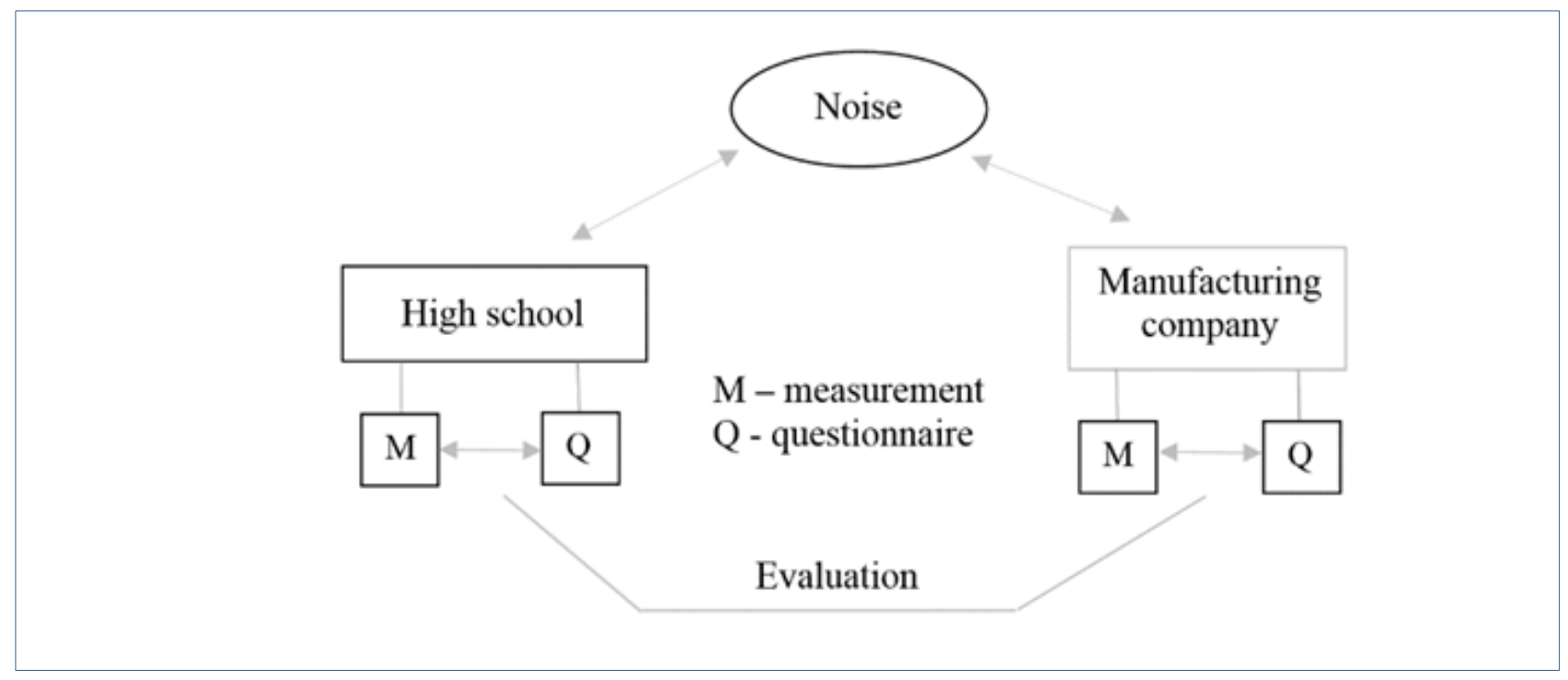

Fig. 1. Research framework.

\subsection{Research environment}

The research was carried out in the Technical High School Ravne and in the manufacturing company Alba, Slovenia, that produces measuring instruments. Slovenia is a small country in Central Europe with two-million inhabitants. It is a part of the European Union. Within industry, the most important sectors are Mechanical and Electro-mechanical/Electronic with more than 2,500 companies, which employ approximately 80,000 people. The bulk of the workforce in the mechanical sector is employed in metalworking and in car component manufacture and assembly. Development and production of electronic components, electrical devices, equipment and systems are the most important areas within electrical engineering, with the 
Vujica Herzog, N.; Buchmeister, B. \& Spindler, L.: Assessment of School and Indu...

following key products: Electro-motors and machines, household appliances, telecommunications equipment, electronic measuring systems, medical and optical equipment, power distribution facilities and electrical components. The selected company Alba therefore presents a typical Slovenian working environment, and the Technical High School Ravne was selected as a comparative environment that can also be very stressful for both participants, teachers and students.

\subsection{Measuring instrument}

For measuring the noise level in the selected environments, a precise modular noise meter was used, Bruel \& Kjaer 2260. Measurements were made at standard working places in the workshops and under normal working conditions according to the SIST IS 9612 Standard. We measured equivalent levels of daily exposure to noise $\left(L_{e x}\right)$ in $\mathrm{dB}(\mathrm{A})$ and evaluated peak level of noise $\left(L C_{\text {peak }}\right)$ in $\mathrm{dB}(\mathrm{C})$ (Rimell et al., 2015). Each measurement was repeated at least four times, and the average value was used for further calculations, the experimental error being max. $3 \mathrm{~dB}$ for $L_{e x}$ values and $4 \mathrm{~dB}$ for peak values.

The measured equivalent noise levels were recalculated to daily and weekly noise levels. Since these values overlapped within the margin of error, only daily noise levels will be presented.

In Europe, the Noise at Work Regulations were unified mostly in the last decade following the Directive 2003/10/EC, and resulting in following exposure limit values and action values:

- The exposure limit values for daily or weekly personal noise exposure is 87 $\mathrm{dB}(\mathrm{A})$ and $140 \mathrm{~dB}(\mathrm{C})$ for peak sound pressure.

- The upper exposure action values are $85 \mathrm{~dB}(\mathrm{~A})$ for daily or weekly noise exposure and $137 \mathrm{~dB}(\mathrm{C})$ for peak sound pressure.

- The lower exposure action values are $80 \mathrm{~dB}(\mathrm{~A})$ for daily or weekly noise exposure and $135 \mathrm{~dB}(\mathrm{C})$ for peak sound pressure.

All our measured values were, therefore, compared to these exposure limits and corresponding actions to be taken.

\subsection{Investigated working environments}

In the company Alba (Fig, 2) measurements were performed in various production plants in the following workplaces: The Joiner's workshop (equipped with a circular saw and other carpenter's tools, Fig. 2.a), the Computer Numerical Control (CNC) workshop (2 rooms: CNC1 with three large milling machines (Fig. 2.b), CNC2 with computer programming the machines in room $\mathrm{CNC} 1$ ), workshop A (equipped with a lathe, milling machine, grinding machine), workshops B and B1 (manual work and assembly), workshop C (manual workshop, assembly, occasional use of manual tools, Fig. 2.c).

At the Technical High School Ravne measurements were made in the English classroom (Fig. 3.a), the corridor, the dining room (Fig. 3.b) and three workshops: Workshop 1 (manual work with metal, use of hammers, grinding, welding and assembly, Fig. 3.c), workshop 2 (use of lathes, Fig. 3.d) and workshop 3 (milling machines). 


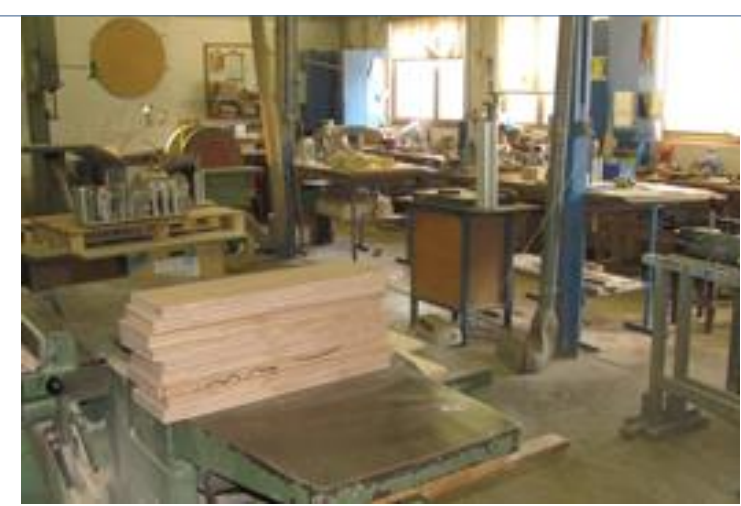

(a)

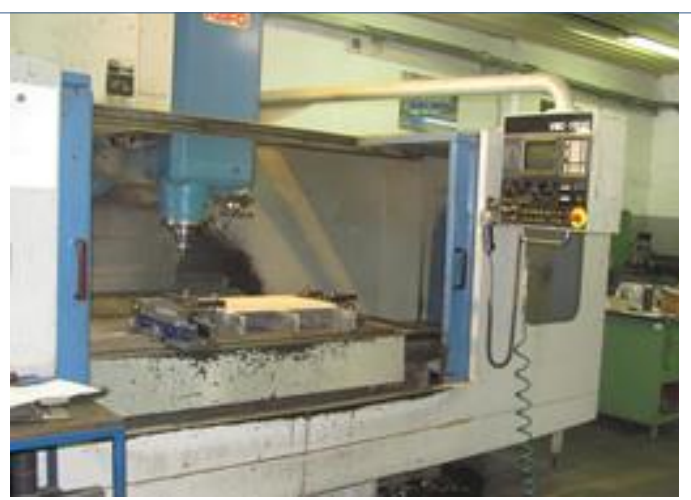

(b)

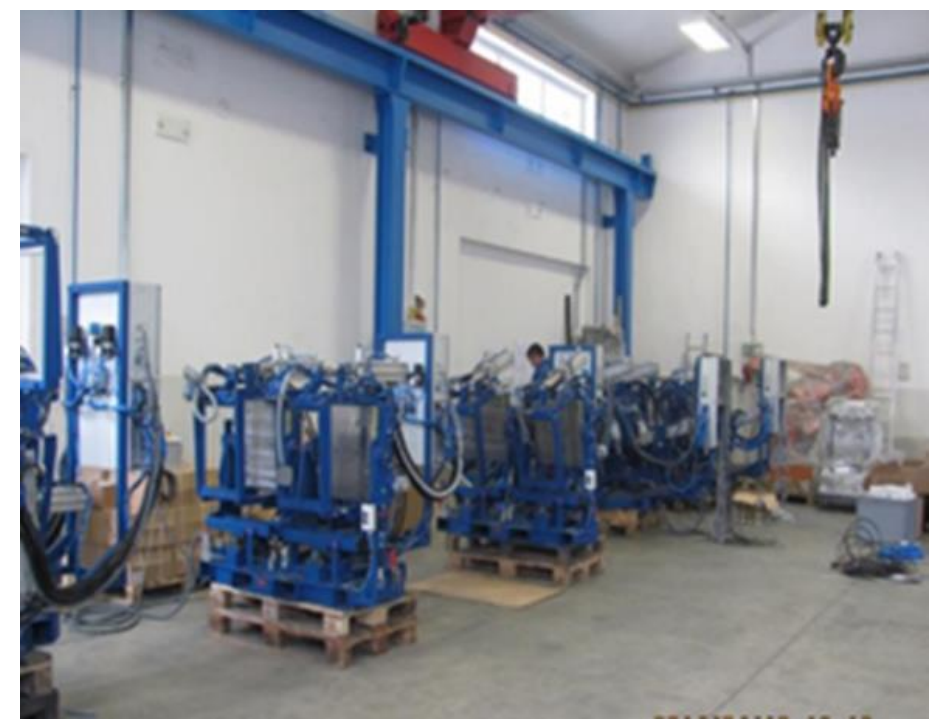

(c)

Fig. 2. Working environments with high noise exposure in company Alba: (a) The Joiner's workshop, (b) CNC1 workshop and (c) Workshop C.

\subsection{Questionnaire}

Although the exact measures of noise are important, they do not give the information of the workers' perception and, therefore, possible negative influence on workers. To study workers' perceptions, a survey research questionnaire was designed, based on extensive literature review.

38 teachers from the Technical High School Ravne and 58 workers from the manufacturing company Alba responded to our survey. The questionnaire contains basic information about the gender, working age and working environment, but the majority of questions is about the workers' perception of noise at work and their influence on workers as a disturbing factor.

To get as much different data as possible, the measuring instrument - questionnaire was designed as a mixture of different types of questions, from multiple-choice questions, ranked questions, questions designed according to the Likert scale to openended questions. 
Vujica Herzog, N.; Buchmeister, B. \& Spindler, L.: Assessment of School and Indu...

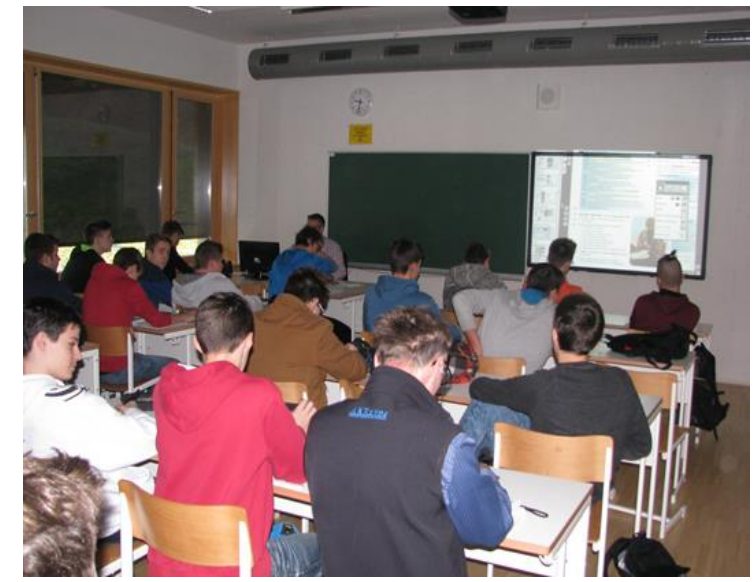

(a)

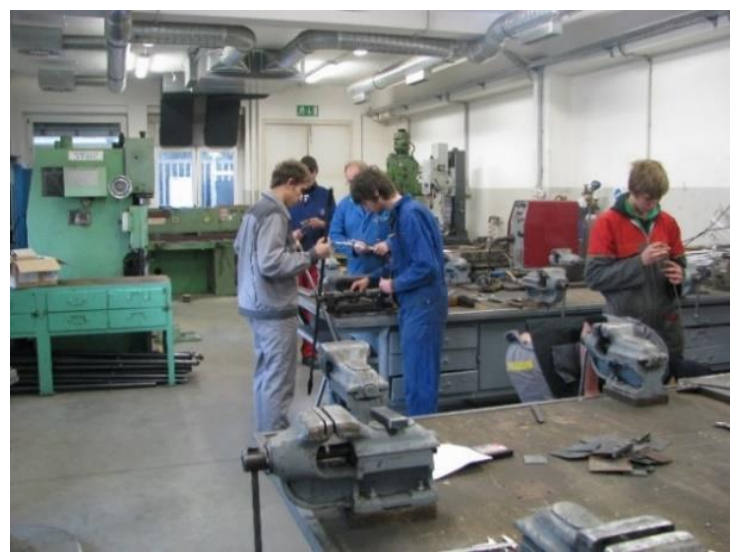

(c)

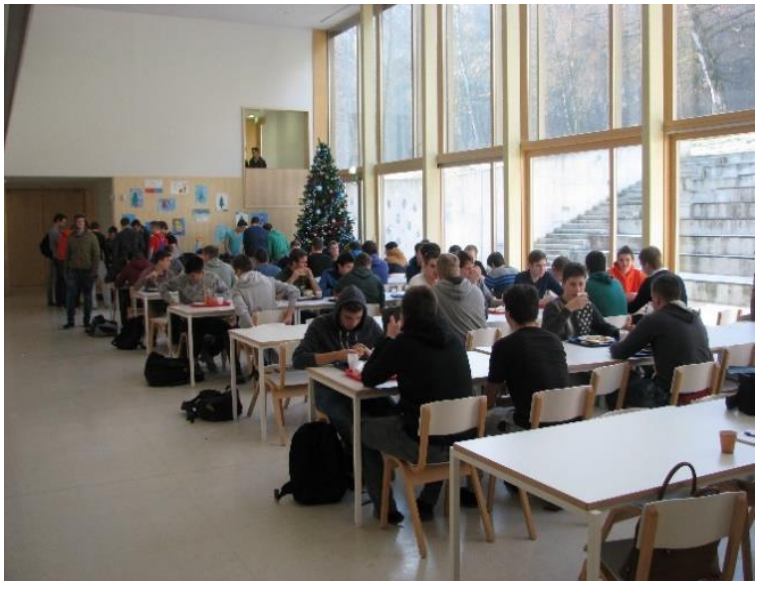

(b)

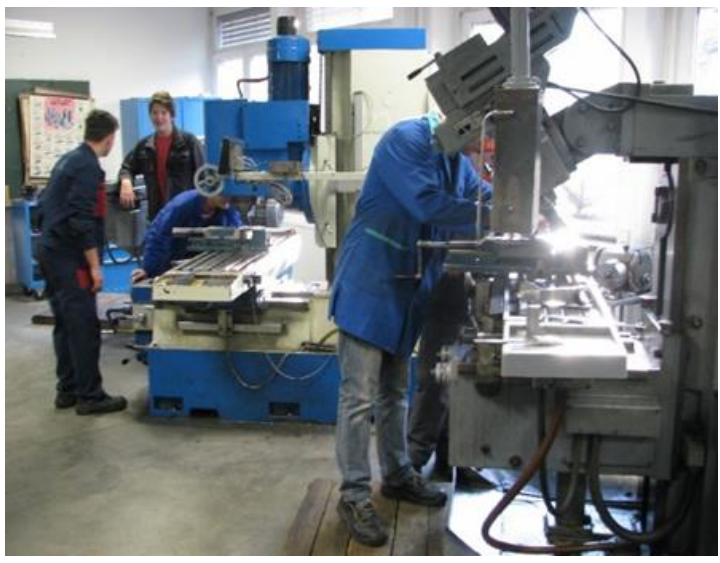

(d)

Fig. 3. Typical working environment at the Technical High School Ravne: (a) English class, (b) Dining room, (c) Workshop 1 during an assembly process, (d) Workshop 2 (lathes).

\section{Results and discussion}

\subsection{Noise measurements}

The performed noise level measurements are summarized in Table 1 (company Alba) and Tables 2 and 3 (Technical High School). In Tables 1 and 2, 8-hours exposure to noise is presented and in Table 3 measured exposures to noise with shorter duration time than 8-hours is. Several high noise levels were registered in the manufacturing company. In one case, (the Joiner's workshop), the boundary level $87 \mathrm{~dB}$ was exceeded by $3 \mathrm{~dB}$, while in workshop A boundary level is reached, and in B1 upper warning level was reached. In such environments, it is obligatory to use hearing protection devices or use other noise control techniques to prevent hearing loss (Wilson, 2016; Mlynski et al., 2014; Koch, 2016). In the company Alba workers use disposable earplugs Howard Leight 303. With them, the noise levels were reduced successfully to a safe level (by about $33 \mathrm{~dB}$ ). 


\begin{tabular}{|l|l|c|c|l|}
\hline $\begin{array}{l}\text { Measuring } \\
\text { place }\end{array}$ & \multicolumn{1}{|c|}{ Activity } & $\begin{array}{c}\text { Daily noise } \\
\text { level } \\
L_{e x}[\mathrm{~dB}(\mathrm{~A})]\end{array}$ & $\begin{array}{c}\text { Peak noise } \\
L C_{\text {peak }}[\mathrm{dB}(\mathrm{C})]\end{array}$ & Noise load assessment \\
\hline $\begin{array}{l}\text { Joiner's } \\
\text { workshop }\end{array}$ & $\begin{array}{l}\text { work with } \\
\text { machines }\end{array}$ & 90 & 114 & Boundary level exceeded \\
\hline W A & work on lathes & 87 & 114 & \multicolumn{2}{|l|}{ Boundary level reached } \\
\hline W B1 & $\begin{array}{l}\text { manual } \\
\text { workshop }\end{array}$ & 85 & 108 & $\begin{array}{l}\text { Upper warning level } \\
\text { reached level }\end{array}$ \\
\hline W B & $\begin{array}{l}\text { manual } \\
\text { workshop }\end{array}$ & 80 & 107 & $\begin{array}{l}\text { Lower exposure level } \\
\text { reached }\end{array}$ \\
\hline W C & $\begin{array}{l}\text { manual } \\
\text { workshop and } \\
\text { assembly }\end{array}$ & 75 & 105 & $\begin{array}{l}\text { Lower exposure level not } \\
\text { exceeded }\end{array}$ \\
\hline W CNC1 & $\begin{array}{l}\text { large milling } \\
\text { machines }\end{array}$ & 82 & 111 & $\begin{array}{l}\text { Lower warning level } \\
\text { exceeded }\end{array}$ \\
\hline W CNC2 & $\begin{array}{l}\text { programming } \\
\text { of machines }\end{array}$ & 56 & 80 & $\begin{array}{l}\text { Lower exposure level not } \\
\text { exceeded }\end{array}$ \\
\hline
\end{tabular}

Tab. 1. Measured noise levels in the manufacturing Company Alba.

In the Technical High School, noise measurements were taken during practical work, during classes and in corridors during a break. Warning levels were exceeded in all workshops (Table 2).

In workshop 1, where manual work with metal, use of hammers, grinding and assembly is conducted, even the boundary level of $87 \mathrm{~dB}$ was exceeded by nearly 4 $\mathrm{dB}$. In all learning workshops it is, therefore, obligatory for the students to use hearing protection devices. In classroom lower exposure level was not exceeded. High noise levels were also measured during students` free time (Table 3), between 71 and $79 \mathrm{~dB}$. Even though these values did not exceed the lower warning level, they were, nevertheless, above the comfort level.

\begin{tabular}{|l|l|c|c|ll|}
\hline $\begin{array}{c}\text { Measuring } \\
\text { place }\end{array}$ & \multicolumn{1}{|c|}{ Activity } & $\begin{array}{c}\text { Daily noise } \\
\text { level } \\
L_{e x}[\mathrm{~dB}(\mathrm{~A})]\end{array}$ & $\begin{array}{l}\text { Peak noise } \\
L C_{\text {peak }}[\mathrm{dB}(\mathrm{C})]\end{array}$ & Noise load assessment \\
\hline W 1 & $\begin{array}{l}\text { hammers, } \\
\text { grinding, } \\
\text { assembly }\end{array}$ & 91 & 121 & Boundary level exceeded & \\
\hline W 2 & lathes & 84 & 110 & $\begin{array}{l}\text { Lower warning level } \\
\text { exceeded }\end{array}$ \\
\hline W 3 & $\begin{array}{l}\text { milling } \\
\text { machines }\end{array}$ & 84 & 122 & $\begin{array}{l}\text { Lower warning level } \\
\text { exceeded }\end{array}$ \\
\hline Classroom & teaching process & 74 & 107 & $\begin{array}{l}\text { Lower exposure level not } \\
\text { exceeded. }\end{array}$ \\
\hline
\end{tabular}

Tab. 2. Measured noise levels during practical work and classes in the Technical High School. 
Vujica Herzog, N.; Buchmeister, B. \& Spindler, L.: Assessment of School and Indu...

\begin{tabular}{|l|l|l|l|l|l|}
\hline $\begin{array}{c}\text { Measuring } \\
\text { place }\end{array}$ & Activity & $\begin{array}{l}\text { Daily } \\
\text { exp. } \\
{[\mathrm{h}]}\end{array}$ & $\begin{array}{l}\text { Daily } \\
\text { noise level } \\
L_{e x}[\mathrm{~dB}(\mathrm{~A})]\end{array}$ & $\begin{array}{l}\text { Peak noise } \\
L C_{\text {peak }}[\mathrm{dB}(\mathrm{C})]\end{array}$ & $\begin{array}{c}\text { Noise load } \\
\text { assessment }\end{array}$ \\
\hline Aula & during a break & 1 & 79 & 116 & $\begin{array}{l}\text { Lower exposure } \\
\text { level not exceeded. }\end{array}$ \\
\hline Corridor & during a break & 1 & 71 & 117 & $\begin{array}{l}\text { Lower exposure } \\
\text { level not exceeded. }\end{array}$ \\
\hline $\begin{array}{l}\text { Dining } \\
\text { room }\end{array}$ & during a break & 1 & 77 & 116 & $\begin{array}{l}\text { Lower exposure } \\
\text { level not exceeded. }\end{array}$ \\
\hline
\end{tabular}

Tab. 3. Measured noise levels during students` free time in the Technical High School Ravne.

\subsection{Frequency analysis}

To gain additional insight into the origin of noise, we performed a frequency analysis of the measured sounds. For each working environment we present both extremes: A working space with little noise, and one with exceeded noise levels. In the company Alba, the quietest room was the programmer's CNC room (CNC2), where only computers were running (Fig. 4a).

The frequencies of the emitted noise were above $100 \mathrm{~Hz}$ and below $5000 \mathrm{~Hz}$, which is well in the comfort zone. In the Joiner's workshop, on the other hand, not only were the boundary levels exceeded, but the noise was distributed over the whole hearing spectrum (Fig. 4b). Uncomfortably high noise values were detected in the high frequency range $(>10 \mathrm{kHz}$ ), as well as a disturbing amount of low frequencies, and even infrasound $(<20 \mathrm{~Hz})$. Both frequency ranges were reported to have irritating or even harmful effects on workers (Smagowska, 2013).

Similar results about the frequency distribution of noise were found in the Technical High School Ravne. The lowest noise levels were measured in the English classroom (Fig. 5a). The students were participating actively in testing their knowledge with the use of an interactive board. No notable low or high frequency noise was detected. Similar frequency distributions were obtained for the hallways, the dining room, and workshops 2 and 3 .

A considerably different noise spectrum was measured for workshop 1 (Fig. 5b). In this place, many different machines are operating (grinding, welding), manual tools are used (hammers) and teachers are explaining the work to the students in elevated voices. All this accounts for a broad distribution of frequencies, ranging from infrasound over the whole audible range and into ultrasound. If one adds the exceeded noise levels, it can be concluded that such working environment is disturbing and rather unhealthy. 


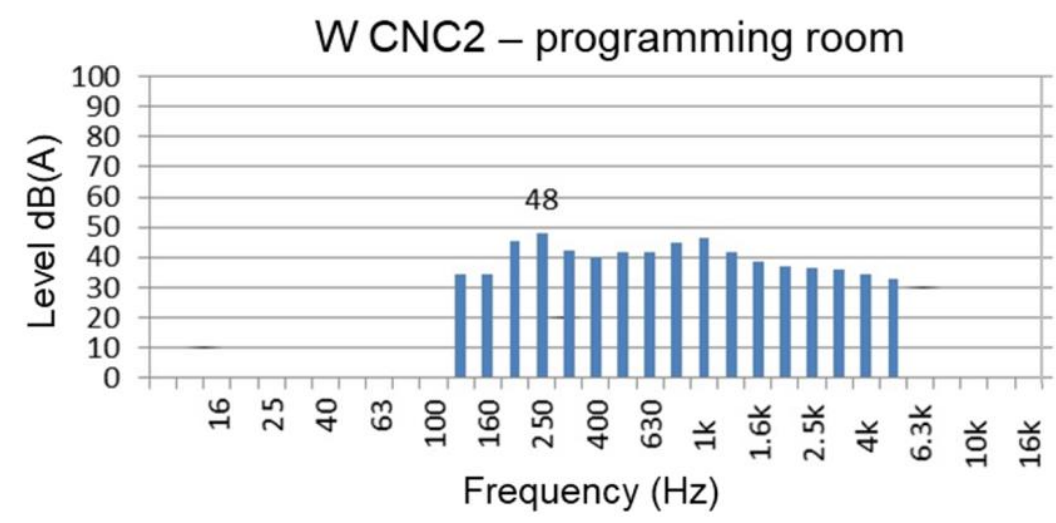

(a)

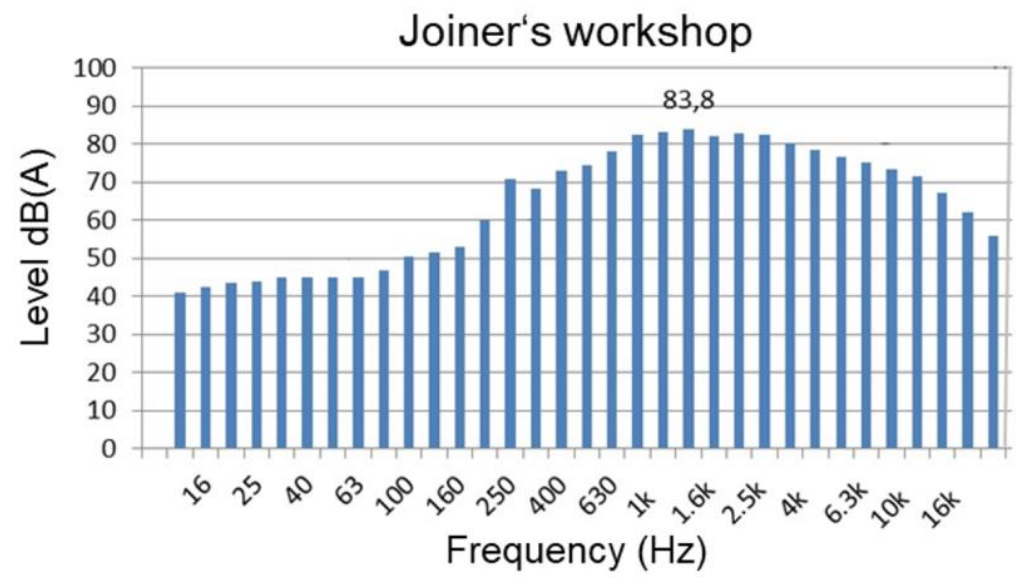

(b)

Fig. 4. Noise frequency analysis in the company Alba: W CNC2 programmer's room with computers (above), the Joiner's workshop with working machines (below).

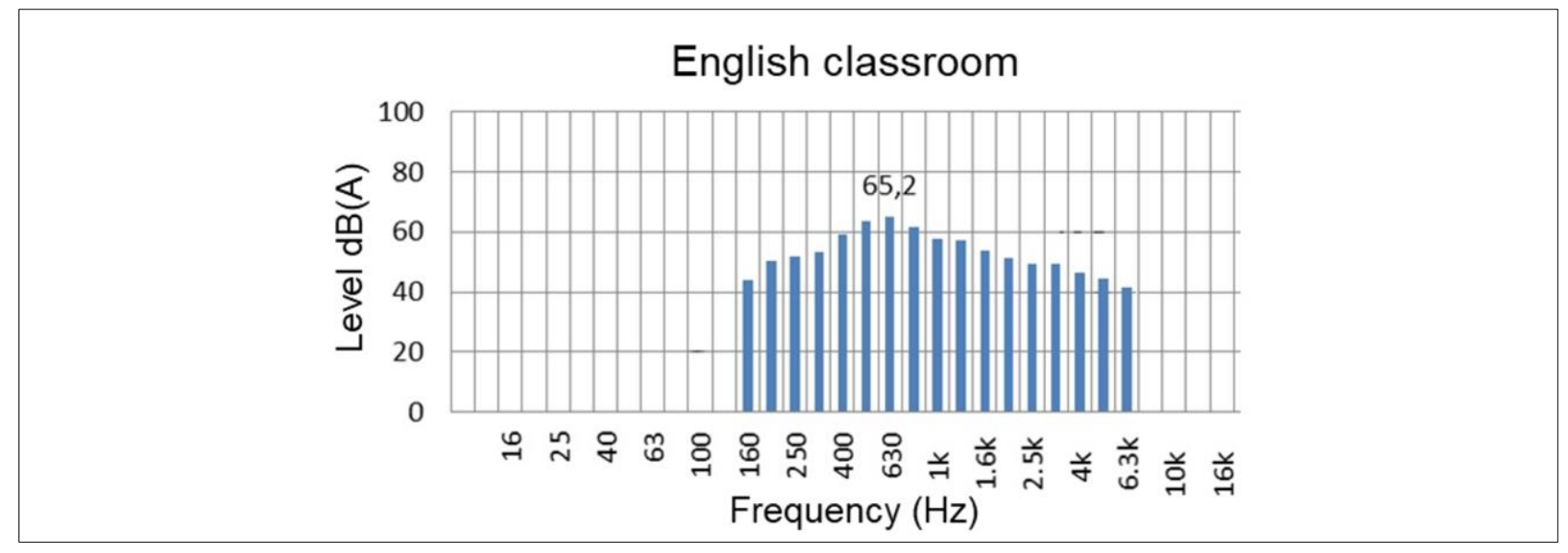

(a) 


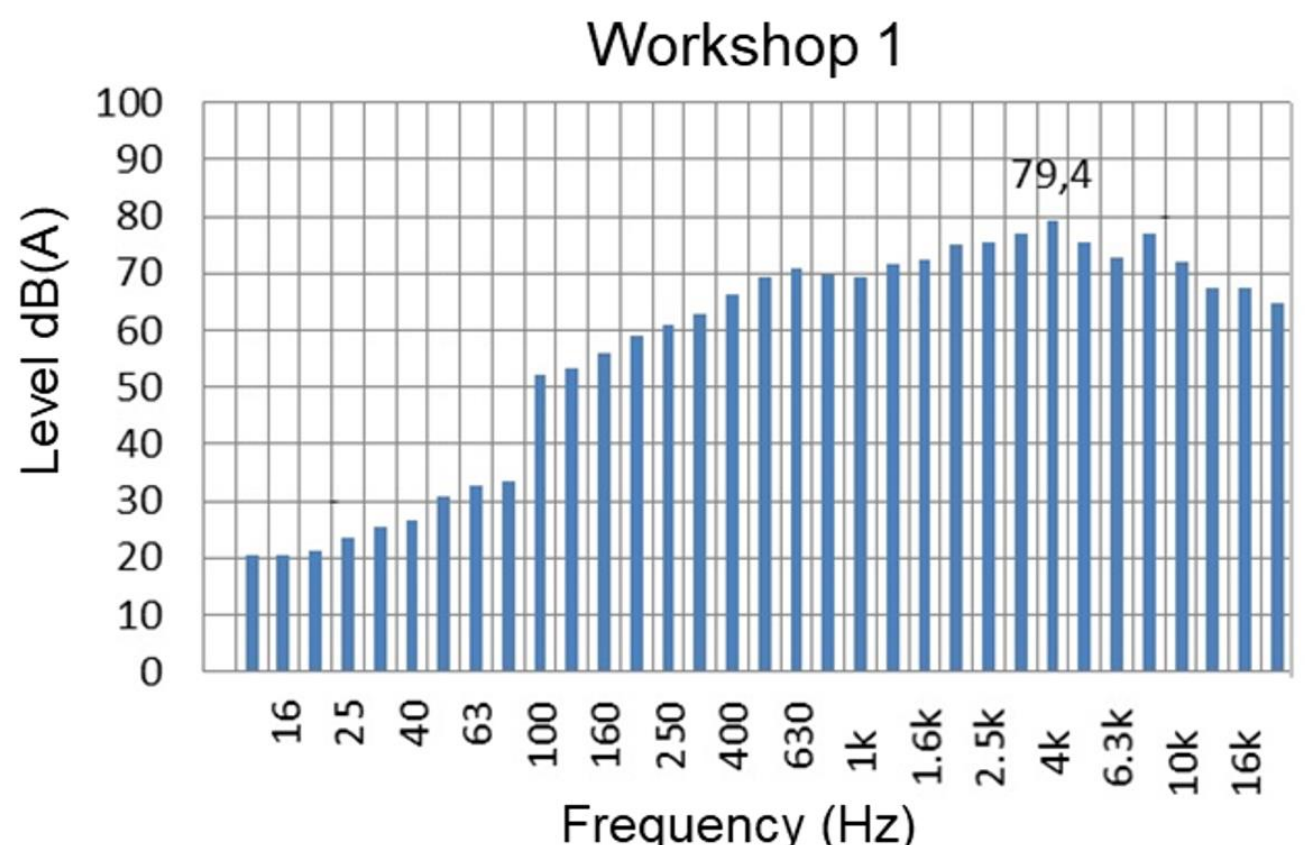

(b)

Fig. 5. Noise frequency analysis in the Technical High School: English classroom during teaching (a), Manual workshop (W1) with grinding and hammer work (b).

\subsection{Questionnaire results}

In the company Alba, 58 workers participated in the survey; of them 56 were male and 2 females. The majority of them were in the $46-55$ years' age group, and had been working in the company for $21-30$ years.

The workers confirmed that they were well informed about the consequences of noise on their health and safety. According to the questionnaire, the most important personal perceptions of the workers regarding workplace related noise were:

- 95\% experience noise at their workplace on a daily basis,

- 78\% experience noise during the whole week,

- workers find the lathe and metal workshops to be places with the highest noise levels,

- the most irritating forms of noise were high frequency noise (hissing noise) and impulsive noise (Mlynski et al., 2014),

- workers find noise levels for simple work procedures to be too high,

- all workers agreed that noise increases stress at the workplace,

- the majority of workers (81\%) know coworkers with hearing impairment,

- three quarters of workers find that noise is often or very often the cause of work accidents (Figure 6), which is in very good agreement with the work reported by Sayed Abas Ali (2011). 


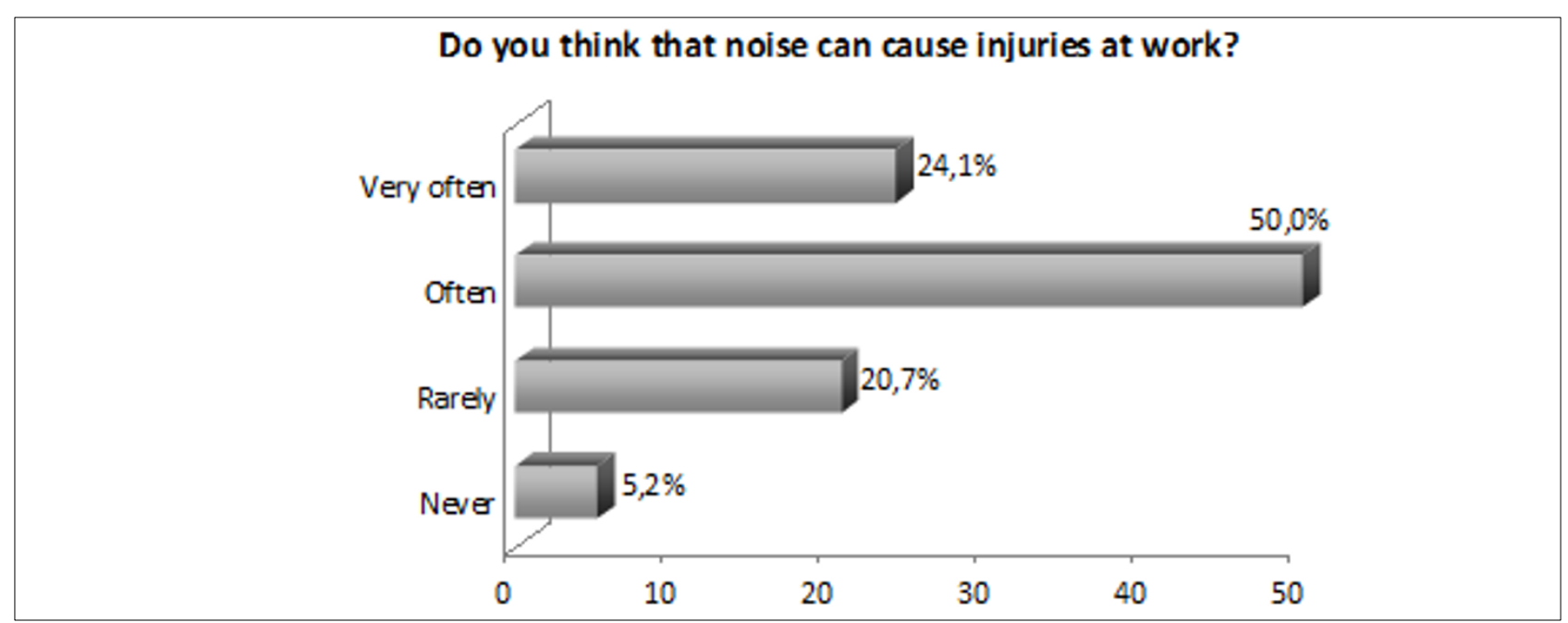

Fig. 6. Results to survey question, "Do you think that noise can cause injuries at work?", for example, because you do not hear a forklift lorry behind you.

The most common psychical responses of workers to noise were (Figure 7): nervousness, tiredness, irritability, and impaired communication to coworkers. The most frequent physical responses were headache and tension or pain in the neck (Figure 8). Workers with hearing impairment experienced tinnitus and they spoke louder. Negative effects of noise on workers were also reflected in an increased intake of food, alcohol consumption and smoking.

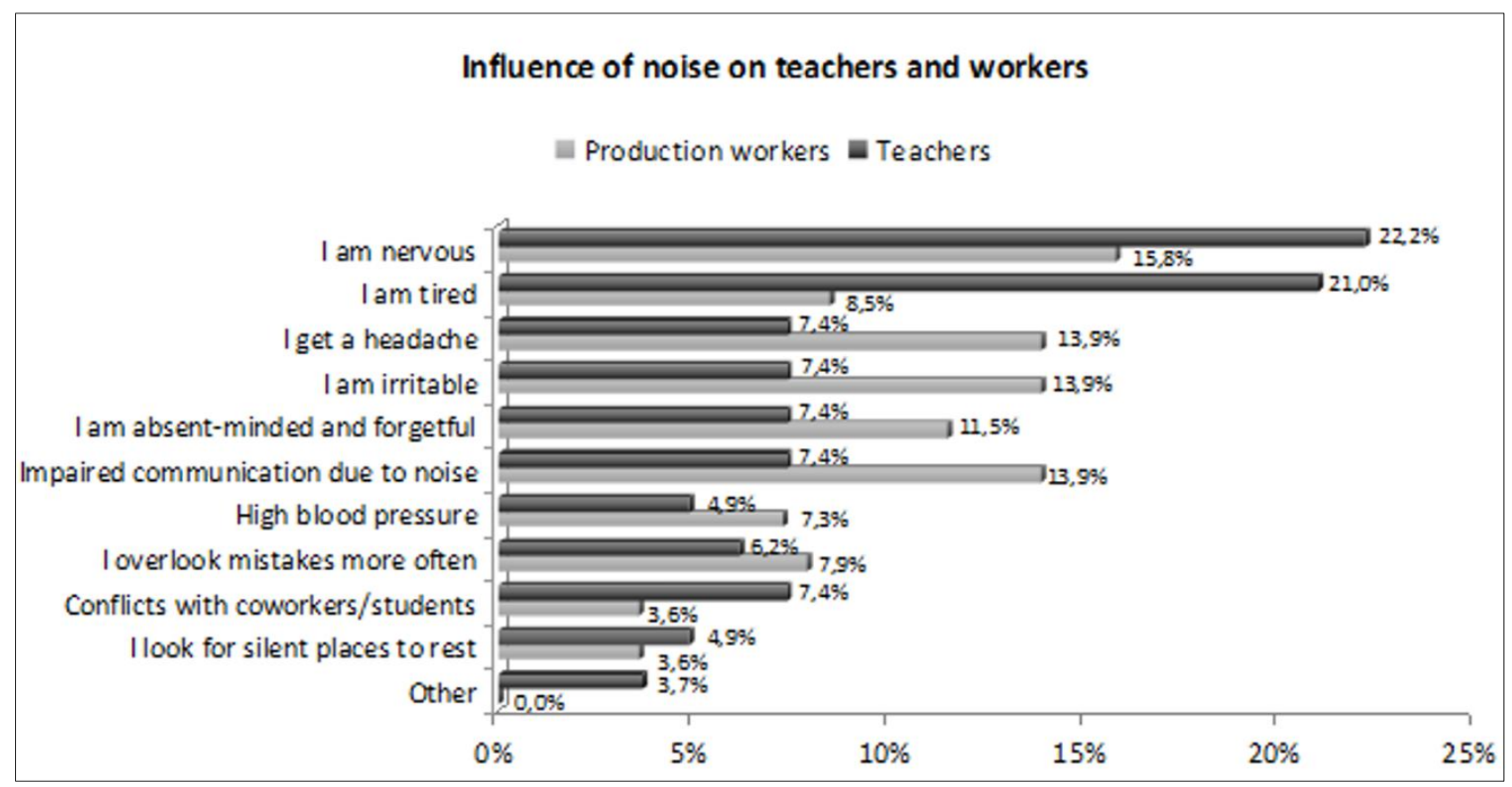

Fig. 7. The influence of noise on teachers and production workers. According to the survey, the main response to noise is nervousness.

The workers in the Alba company were also asked what personal measures they use to decrease noise levels and what were their suggestions to decrease noise at their workplace. $66 \%$ of workers regularly used ear plugs and $27 \%$ headphones to protect their hearing. Additionally, they turn off machines that are not needed in order to decrease ambient noise. To improve the working environment further, the workers 
Vujica Herzog, N.; Buchmeister, B. \& Spindler, L.: Assessment of School and Indu...

suggested moving the loudest machines and gathering them in one large room (rearranging of the workflow). At home, workers preferred to be in silence (Figure 9) and found relaxation most frequently in outdoor activities or meeting friends.

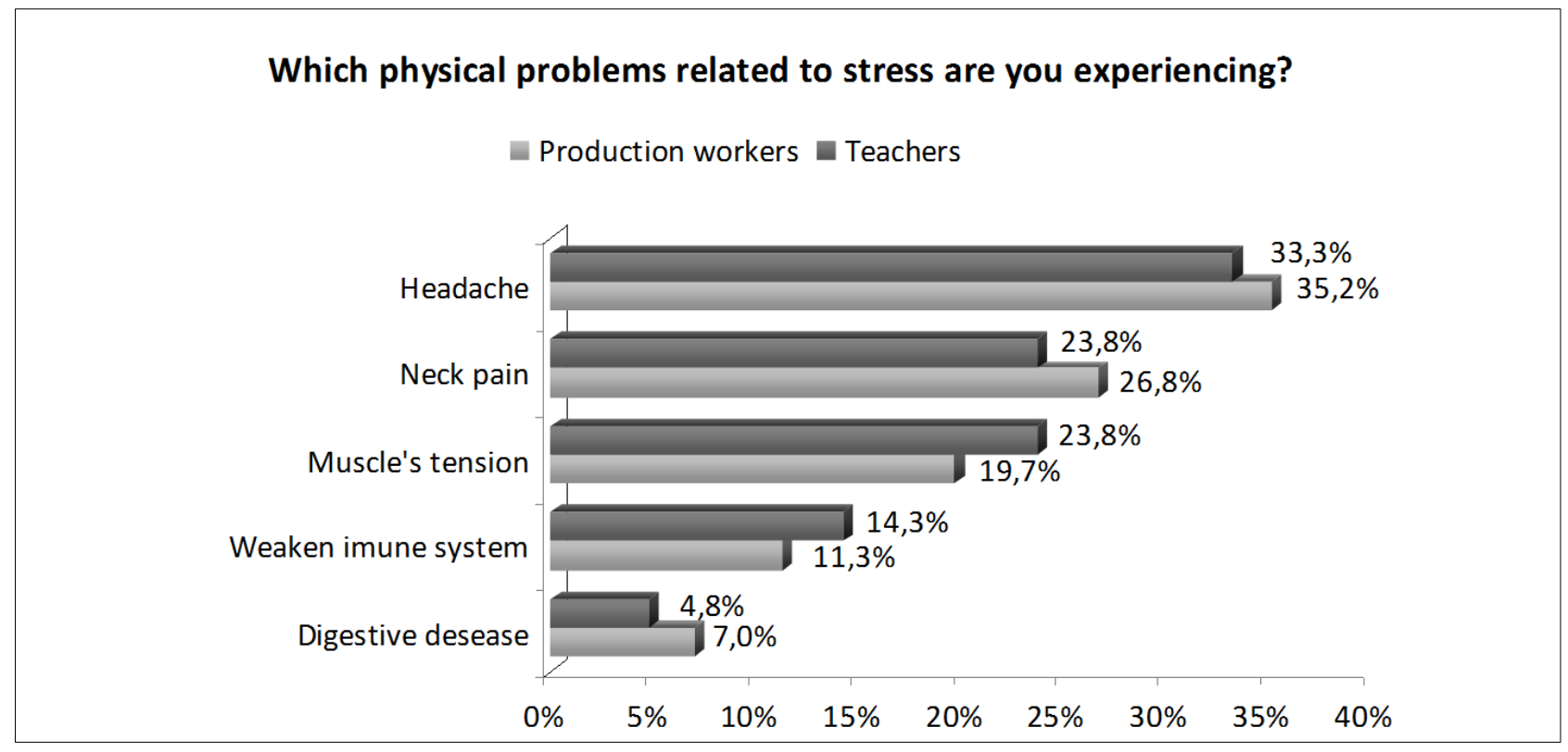

Fig. 8. Physical problems related to noise-induced stress.

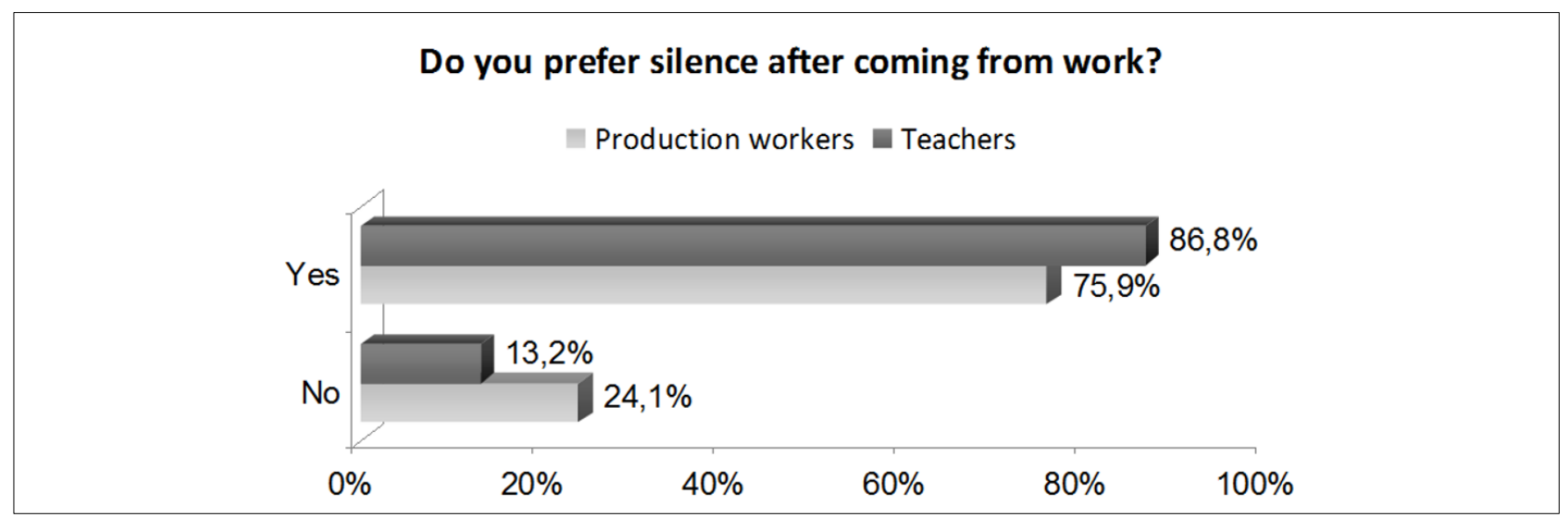

Fig. 9. Teachers prefer silence more than production workers when at home.

In the Technical High School Ravne, 38 teachers participated in the survey; of them 15 were male and 23 female. The majority of them were in the $35-45$ years age group and had been working in the school for $11-20$ years. Only half of the teachers confirmed that they were well informed about the harmful consequences of noise.

According to the questionnaire, the most important personal perceptions of teachers regarding school-related noise were:

- 74\% experienced noise at the workplace on a daily basis,

- 17\% experienced the highest noise levels on Fridays, and 14\% on Mondays,

- the highest daily noise levels were between 9 and 11 o'clock,

- the main cause of noise were students' activities and activities outside the school such as traffic,

- inside school, teachers find the corridors and practical workshops to have the highest noise levels, 
- as most irritating were declared the high pitched noises,

- most of the teachers found that the noise levels for intellectual work were sometimes exceeded, which is known to decrease teachers' concentration and performance (Ali, 2013),

- all teachers agreed that noise increased their stress at the workplace,

- the majority of teachers didn't experience hearing impairment.

The most common psychical responses of teachers to noise were (Figure 7): nervousness and tiredness. The most frequent physical responses were headache, backbone pain, and muscle tension (Figure 8). Negative effects of noise on teachers were reflected in an increased intake of food (50\%) and smoking (42\%). Nearly $75 \%$ of all illnesses where teachers needed medical care were stress related.

In order to decrease noise in the classrooms, teachers reminded students to keep quiet or they started talking in a low voice to force students to listen (Figure 10). To reduce ambient noise further, the teachers suggested arranging special rooms where students could wait during their free time. All these were teachers' subjective opinions, as there are only a few scientific studies on effective noise reduction in spaces with numerous occupants (Koch et al., 2016; Gerhardsson et al., 2013; Kristiansen, 2016). At home, teachers preferred to be in silence (Figure 9) and found relaxation most frequently in meeting friends and activities in nature.

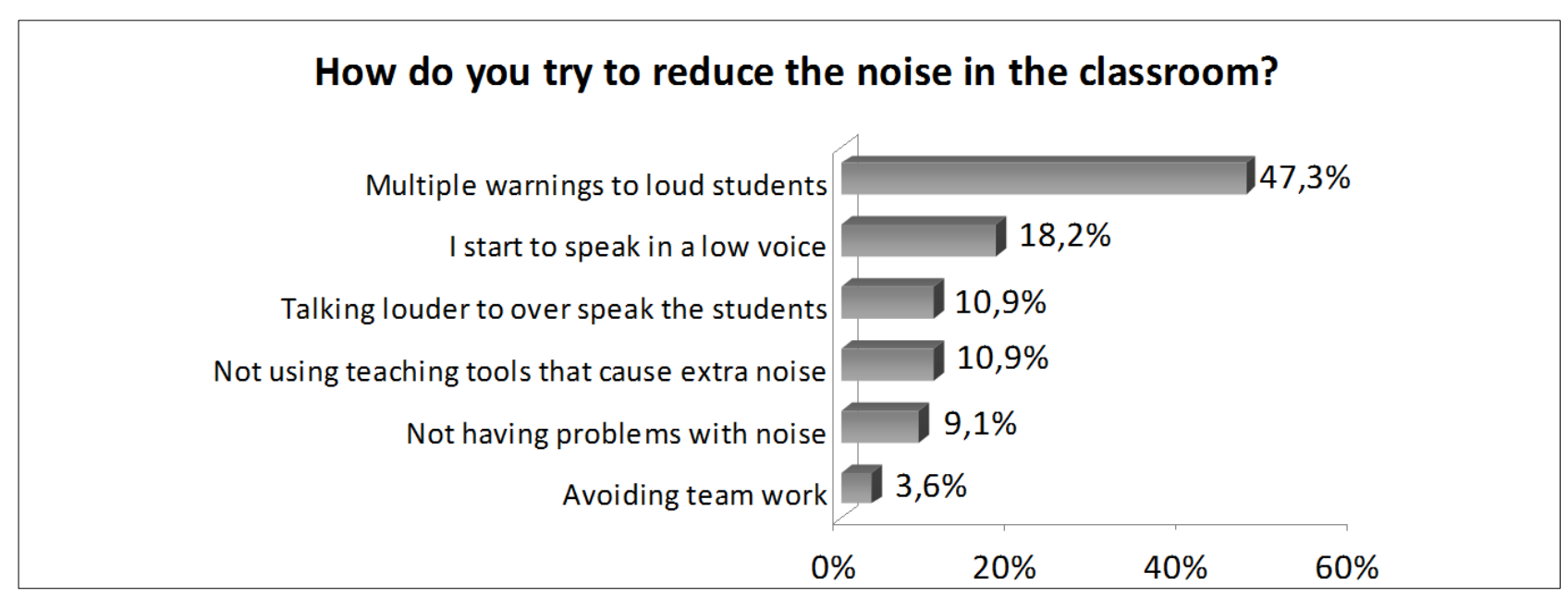

Fig. 10. According to the survey, teachers most frequently use multiple warnings to loud students to achieve better working conditions in the classroom.

\section{Conclusions}

Noise in the working environment and on particular workplaces presents several risks for the worker, either by direct effects such as hearing loss and possible deafness by the time of retirement, or by extra-aural effects from long-term exposure to noise, resulting in psychical problems, harmful effects on the autonomous nerve system, cardiovascular system or the organism in general. These extra-aural affects are not listed as health threats in the European or Slovenian legislation and therefore (also?), not enough studies were dedicated to this problem.

In our study subjective and objective measures were performed for noise level assessments in two different environments. Comparison of perceived and measured 
Vujica Herzog, N.; Buchmeister, B. \& Spindler, L.: Assessment of School and Indu...

noise level is not common practice in manufacturing environment. Usually noise measurements are performed by authorized performer in accordance to legislation but subjective measures are rare.

Results of our research show that there are noticeable correlations between objective measures and subjective measures gained with performed survey research. The upper noise level of $85 \mathrm{~dB}(\mathrm{~A})$ was exceeded in the Company Alba on two workplaces: a workshop with grinding, hammering, milling, large machines, and in the Joiner's workshop (Table 1). This is comparable with personal perceptions of workers gained with questionnaire, where workers find the lathe and metal workshops to be places with the highest noise levels. Workers also exposed high frequency noise and impulse noise as the most irritating forms of noise and this kind of noise is according to our measurements evidenced in workshops (Figure 4 and 5). This agrees well with the assessment of impulse noise as a health hazard (Mlynski et al., 2014).

Even though other measured noise levels in company Alba were lower, questionnaire results show that the majority of worker's experience noise at their workplaces daily. All workers also agreed that noise increases stress at workplace.

In the Technical High School, noise levels were similarly exceeded in the metalhandling workshop with hammer work, grinding and assembly processes (Table 2). In this workshop and all metal-handling workshops in company Alba, it is obligatory for the workers to be equipped with personal hearing protection devices, most frequently with disposable earplugs, which lower the noise levels by an average of $33 \mathrm{~dB}$.

Although in the Technical High School boundary noise levels in the classrooms and corridors were not exceeded, their values were uncomfortably high (for example $74 \mathrm{~dB}(\mathrm{~A})$ in the English classroom). This is an underestimated risk for the teachers who experience such noise levels on a long-term basis. Not surprisingly, most teachers reported nervousness and tiredness as their main responses to daily noise (Figure 7).

We can conclude, that in general, there was a good correlation between the measured noise levels in the working environments and the personal perception of the workers on their harmful effects. Questionnaire results show that workers perceived all harmful effects that are expected to be possibly harmful regarding the measured noise levels. Performed survey gave us even better insight into research problems and more precise information's about noise effects and possible consequences on workers' health and wellbeing. Results of our research show that in future legislation should be supplemented with consideration of the extra-aural effects on the workers.

\section{Acknowledgements}

The authors acknowledge Mrs. Sabina Hrasan that performed research as part of her Master thesis. This work was supported by the Slovenian Research Agency in the framework of Grant P2-0190.

\section{References}

Ali, S. A. (2011). Industrial noise levels and annoyance in Egypt, Applied Acoustics, Vol. 72, No. 4, pp. 221-225 
Ali, S. A. (2013). Study effects of school noise on learning achievement and annoyance in Assiut city, Egypt, Applied Acoustics, Vol. 74, No. 4, pp.602-606

Akboğa, Ö.; Kale, Bayram, İ.; Baradan, S. (2019). Evaluating noise exposure levels of laboratories in civil engineering education, Noise Control Engineering Journal, Vol. 67, No. 2, pp. 69-79

Argalasova L., et al. (2016). The Risks of Social Noise Exposure in the Vulnerable Population in Slovakia, Archives of acoustics, Vol. 41, No. 3, pp. 535-541

Beach, E.; Williams, W.; Gilliver, M. (2011). Noise level assessments: Subjective vs objective measures, Proceedings of Acoustics 2011, p. 140

Brink, M.; Schreckenberg, D.; Vienneau, D.; Cajochen, C.; Wunderli, J. M.; Probst Hensch, N.; Röösli, M. (2016). Effects of Scale, Question Location, Order of Response Alternatives, and Season on Self-Reported Noise Annoyance Using ICBEN Scales: A Field Experiment, International Journal of Environmental Research and Public Health, Vol. 13, p. 1163

Buchmeister, B.; Palcic, I.; Ojstersek, R. (2019). Artificial Intelligence in Manufacturing Companies and Broader: An Overview, Chapter 07 in DAAAM International Scientific Book 2019, pp. 081-098, B. Katalinic (Ed.), Published by DAAAM International, ISBN 978-3-902734-24-2, ISSN 1726-9687, Vienna, Austria, DOI: $10.2507 /$ daaam.scibook.2019.x

Chetoni M.; Fredianelli L.; Minichilli F.; Cori L.; Licitra G.; Bianco F. (2016). Correlation between perceived and measured noise, within the GIOCONDA project, Proceedings of the 23rd International Congress on Sound \& Vibration, Athens, Greece Directive 2003/10/EC of the European Parliament and of the Council of 6 February 2003 on the minimum health and safety requirements regarding the exposure of workers to the risks arising from physical agents (noise)

Gerhardsson L. \& Nilsson E. (2013). Noise Disturbances in Daycare Centers Before and After Acoustical Treatment, Journal of Environmental Health, Vol. 75, No. 7, pp. $36-40$

Gilavand A. (2016). Investigating the Impact of Environmental Factors on Learning and Academic Achievement of Elementary Students: Review, International Journal of Medical Research and Health Sciences, Vol. 5, No. 7, pp. 360-369

Giorgi G., Leon-Perez J. M., Cupelli V., Mucci N., Arcangeli G. (2014). Do I Just Look Stressed or am I Stressed? Work-related Stress in a Sample of Italian Employees, Industrial Health, Vol. 52, No. 1, pp. 43-53,

Harari Y.; Bechar A.; Raschke U.; Riemer R. (2017). Automated Simulation-Based Workplace Design that Considers Ergonomics and Productivity. International Journal of Simulation Modelling, Vol. 16, No. 1, pp. 5-18

Lee, J.; Francis, J. M.; Wang, L. M. (2017). How tonality and loudness of noise relate to annoyance and task performance, Noise Control Engr. J. Vol. 65, No. 2, pp. 71-82, Koch, P.; Stranzinger, J.; Kersten, J.F.; Nienhaus A. (2016). Use of moulded hearing protectors by childcare workers - an interventional pilot study, Journal of Occupational Medicine and Toxicology, No. 11, pp. 1-10

Kristiansen J., et al. (2016). The effects of acoustical refurbishment of classrooms on teachers' perceived noise exposure and noise-related health symptoms, International Archives of Occupational and Environmental Health, Vol. 89, No. 2, pp. 341-350 
Vujica Herzog, N.; Buchmeister, B. \& Spindler, L.: Assessment of School and Indu...

Lynn, K. (1999). Measurement made accessible, A research Approach Using Qualitative, Quantitative \& Quality Improvements Methods, SAGE Publications, Thousand Oaks London New Delhi.

Mlynski R.; Kozlowski E.; Adamczyk J. (2014). Assessment of Impulse Noise Hazard and the Use of Hearing Protection Devices in Workplaces where Forging Hammers are Used, Archives of Acoustics, Vol. 39, No. 1, pp. 73-79

Distefano, N. \& Leonardi, S. (2019). Experimental investigation of the effect of roundabouts on noise emission level from motor vehicles, Noise Control Engineering Journal, Vol. 67, No. 4, pp. 282-294

Nunnally, J. C. \& Bernstein, I. H., (1994), Psychometrics Theory, 3rd edition, McGraw-Hill, New York.

Rimell, A.; Mansfield, N. J.; Paddan, G.S. (2015). Design of digital filters for frequency weightings (A and $\mathrm{C}$ ) required for risk assessments of workers exposed to noise, Industrial Health, Vol. 53, No. 1, pp. 21-27

Sadick A.M. \& Issa M.H. (2017). Occupants' indoor environmental quality satisfaction factors as measures of school teachers' well-being, Building and Environment, 119, 99-109

Sajin, S.; Chin, C.S.; Neo, J. (2019). Acoustics vs. psychoacoustics: An objective and subjective analysis of classroom acoustics in Singapore, Noise Control Engineering Journal, Vol. 67, No. 2, pp. 80-97

Smagowska, B. (2013). Ultrasonic Noise Sources in a Work Environment, Archives of Acoustics, Vol. 38, No. 2, pp. 169-176

Vilcekova, S.; Meiarova, L.; Kridlova Burdova, E.; Katunska, J.; Kosicanova, D.; Doroudiani S. (2017). Indoor environmental quality of classrooms and occupants' comfort in a special education school in Slovak Republic, Building and Environment, $120,29-40$

Vujica Herzog, N.; Buchmeister, B. \& Harih, G. (2019). Ergonomics workplace design for workers with disabilities, Chapter 12 in DAAAM International Scientific Book 2019, pp. 159-147, B. Katalinic (Ed.), Published by DAAAM International, ISBN 9783-902734-24-2, ISSN 1726-9687, Vienna, Austria, DOI: 10.2507/daaam.scibook.2019.x

Xie, H.; Kang, J.; Tompsett, R. (2011). The impacts of environmental noise on the academic achievements of secondary school in Greater London, Applied Acoustics, Vol. 72, No. 8, pp. 551-555

Yan, L. \& Jiang, W. (2014). "Research on the procedure for analyzing the sound quality contribution of sound sources and its application", Applied Acoustics, Vol. 79, pp. 7580

Wang, P.; Wang, Y.; Zou, C.; Guo, J. (2017). A preliminary investigation of noise impact within metro stations in the urban city of Guangzhou, China, Environmental Science and Pollution Research, Vol. 24, Nr. 12, pp. 11371-11382

Wilson, P. (2016). Top 10 Noise Control Techniques: 2015, Acoustics Australia, Vol. 44, No. 1, pp. 33-43 